\title{
Biological Properties and Antioxidant Activity of Hawthorn Crataegus mexicana
}

Banderas-Tarabay José Antonio ${ }^{1,2}$, Cervantes-Rodríguez Margarita ${ }^{1}$ and Méndez-Iturbide Daniel ${ }^{{ }^{*}}$

${ }^{1}$ Food and Chemistry Laboratory, School of Nutrition and Faculty of Medical Sciences, Universidad Autónoma de Tlaxcala, Av. Xicohtencatl No. 466, Barrio de San Nicolás, San Pablo del Monte 90920, Tlaxcala, Mexico

${ }^{2}$ Centro Tlaxcala de Biología de la Conducta (CTBC), Universidad Autónoma de Tlaxcala, Tlaxcala, Mexico

\begin{abstract}
The traditional fruit in Mexico represent a great variety of species with nutritious properties and with a wide field of usage in traditional medicine. "Tejocote" (hawthorn) is a fruit with medicinal properties since pre-hispanic times due to its high content of Vitamin A, Vitamin C, minerals, oligomeric procianidines, triterpenes, carotenes, flavonoids, polysaccharides and catecholamines. Some of these compounds are used to treat cardiovascular diseases, as well as immune diseases and respiratory problems such as colds and cough, neurological problems, eye disease, reproductive organs disease, and in the liver and kidneys, since "tejocote" has citotoxic activity, gastro protective, anti-inflammatory, anti-viral and anti-microbian. The current review is focused on the botanical features, ethnobotanical and phytochemical of the "tejocote" from the gender Crataegus mexicana, which is the variety grown and most consumed in our country. There are very few studies concerning its contents of metabolites, its potential use as anti-oxidant and its applications in order to treat some diseases.
\end{abstract}

Keywords: Biological properties; Crataegus mexicana; Hawthorn; Antioxidant; Phytochemistry

\section{Introduction}

In Mexico, there is a great variety of plants and fruit with a wide genetic diversity, being useful for agriculture, industry, medicine and with alimentary potential of diverse nature, which have not been explored nor exploited appropriately [1,2]. Knowing the chemical properties and nutritional content of fruit is one of the first steps to its application on several nutritional conditions. Within this great diversity of fruit, there are different species of "tejocote" which have a great deal of medicinal applications, but only a few have been analyzed in order to determine its biological activity, such as is the case of the hawthorn Crataegus mexicana.

\section{Origin}

The name "tejocote" comes from Nahuatl "tetl (stone) - xócotl (fruit)", which means hard fruit and acid or sour [3] similar to the name given to the apple tree, the Nahoas from this same ethnic group, calling it texococuahutl, which means: the Indian apple tree [4-6]. When Spaniards arrived in the "new continent" named it "little apple" due to its similarity of this fruit with apples. This name subsists today in the southwest of the Mexican Republic, in the states of Chiapas and Oaxaca, that is why it is also called little apple and "untamed tejocote". In the State of Mexico npeni in Otomi language, and pedyi in Mazahua language [5]. In Michoacán it is known as karhasi or carasu in Tarasco or Purépecha language [7,8], in Oaxaca is called belohui, in Zapotec language. In English is named Hawthorn or Mexican Wild Crabapples. In Europe, the word "haw", is an old form of "hedge", which means fence or limit, since it was used to limit pieces of land, since there are varieties that due to its resistance are hard to eliminate. In México, "tejocote" tree also has an ornamental use.

Traditionally in México, "tejocote" is a fruit used as food, whether can be consumed directly fresh or prepared in a traditional drink called "ponche", which is a brewed drink made with different fruit; also is used as ornament or to fill "piñatas" in some traditional Mexican festivities, such as: Day of the Dead, Independence Day, and Christmas time "posadas". "Tejocote" is prepared as well for consumption in the forms of marmalade, gelatin, jelly and candy [9].

\section{Phylogenetic Origin of "Tejocote"}

"Tejocote" is considered to be a typical fruit of México since prehispanic times, although different varieties can be found in other parts of the world, such as: North of Africa, Eastern Asia, Middle East, India, China, Europe and North America; and it has been introduced to other countries such as Tasmania, England and Himalayan.

Evidence show that the type Crataegus was originated in the Tertiary Age, and it seems, there were developed two parallel lines of evolution; one in Asia and the other in the North of America. Without a doubt the species of Crataegus from Europe are derived from Central Asia and China. The specie of Crataegus that predominates in Mexico is Crataegus mexicana, "tejocote mexicano", and although, there are doubts about its phylogenetic origin, it is believed that was originated from C. scabrifolia, which has its habitat in the East of the Asian Continent; nevertheless, is not discarded that México is the possible center of its origin $[8,10]$.

\section{Taxonomic Classification}

From the year 372-287 B.C. in Greece, the philosopher Theophrastus gave the first description of the kind, giving it the name of Krataigos (kratos=hard wood, resistant). The type Crataegus, is constituted by approximately 280 species dispersed through all over the world [11], although it is mentioned that can be $140[12,13]$, and other authors mention from 150 to 200 species $[6,8,14]$, from which 95 of them are

*Corresponding author: Méndez-Iturbide Daniel, Food and Chemistry Laboratory School of Nutrition and Faculty of Medical Sciences, Universidad Autónoma de Tlaxcala. Av. Xicohtencatl No. 466, Barrio de San Nicolás, San Pablo del Monte 90920, Tlaxcala, México, Tel: 55246 4626908; E-mail: danychem@yahoo.com.mx

Received October 02, 2015; Accepted October 30, 2015; Published November 06,2015

Citation: Antonio BTJ, Margarita CR, Daniel MI (2015) Biological Properties and Antioxidant Activity of Hawthorn Crataegus mexicana. J Pharmacogenomics Pharmacoproteomics 6: 153. doi:10.4172/2153-0645.1000153

Copyright: (c) 2015 Antonio BTJ et al. This is an open-access article distributed under the terms of the Creative Commons Attribution License, which permits unrestricted use, distribution, and reproduction in any medium, provided the original author and source are credited. 
Citation: Antonio BTJ, Margarita CR, Daniel MI (2015) Biological Properties and Antioxidant Activity of Hawthorn Crataegus mexicana. J Pharmacogenomics Pharmacoproteomics 6: 153. doi:10.4172/2153-0645.1000153

Page 2 of 8

found in the American Continent, divided into 40 series, from which two thirds are found in North America and the rest in Europe and Asia. The taxonomy of this type has been reported as one of the most complex among superior plants at world level [12], which has provoked serious identification problems and homonymies $[13,15]$. Upon based on the studies of [12,16-19], the most recent taxonomy of the kind for Mexican specimens is described on (Table 1).

In México, the most common name for the type Crataegus is the "Tejocote", in particular for Crataegus mexicana. Since 1997 it considered that the term pubescens is used wrong and should not be utilized [20], being correctly referred as C. gracilior [18].

\section{Characteristics of the Fruit}

"Tejocote" is grown in trees and bushes that can reach between 5 to 10 meters of height, their leaves are semi-perennial, oval shaped or diamond shaped, 4 to 8 centimeters in length and serrated edge, although there are Asian varieties with smaller leaves of $15 \mathrm{~mm}$ to 5 centimeters in length (WHO, 2003). Their flowers are in a range of colors that goes from white, pink to red, and are grown in clusters of 5 to 12 pieces, and can contain both sexes, being pollinized by insects which are attracted by its aroma. It is developed mostly in the north hemisphere between the latitudes $30^{\circ}$ and $50^{\circ}$. It is a small fruit, balloon and oblong shaped, from which have been reported up to 37 morphologic variables $[1,8,21]$. It is a seasonal fruit, although it can be found throughout the year in some regions of the country, when ripe its tonalities vary from orange-yellow to reddish-yellow, is aromatic with and essence of trimethylamine [22], meaty and a very good flavor, which can have one or two seeds (Figure 1).

\section{Distribution in México}

In México, there have been reported 13 species in the center and north of the country, and two more in the south as well $[18,23]$, being the most utilized for consumption and industrialization the varieties of Crataegus mexicana and Crataegus gracilior. Species of this type have been reported found in 20 of the 32 states of the Mexican Republic, in altitudes that go from 400 to 3,000 meters above sea level, in damp weathers, semi-dry and dry.

It is distributed principally in the State of Mexico, Puebla, Tlaxcala, Chiapas, Michoacán, Hidalgo and Morelos. In the North of the country above all Coahuila and Nuevo León, the red "tejocote" is also edible (Crataegus greggiana). It is distributed in the most of the mountain zones of México, above all in the neovolcanic axis (from the state of Veracruz up to the state of Jalisco), the Sierra Madre Oriental (between the states of Hidalgo, Tamaulipas, San Luis Potosí, Coahuila and Nuevo León), the Sierra Madre of the South (the sierra of Oaxaca and Guerrero) and the high areas of Chiapas [2] (Figure 2).

The states of Oaxaca, México, Puebla and Tlaxcala are among the principal producers of "tejocote" in México. From these, they are classified in two types: "criollos" and cultivated, the first ones are located between the $14^{\circ}$ and $32^{\circ}$ of north latitude, and the cultivated ones between the $19^{\circ}$ and $20^{\circ}$ of north latitude [8].

\begin{tabular}{|c|c|c|c|}
\hline Series & Family & Subespecie & Geographic area \\
\hline 1. Parvifoliae & 1. C. uniflora & & Tamaulipas \\
\hline \multirow[t]{3}{*}{ 2. Mexicanae } & 2. C. mexicana & & $\begin{array}{l}\text { Tlaxcala, Estado de México, Hidalgo, Puebla, Michoacán, Jalisco, } \\
\text { Guanajuato, Veracruz }\end{array}$ \\
\hline & $\begin{array}{l}\text { 3. C. stipulosa (synonymy } C \text {. } \\
\text { mexicana) }\end{array}$ & & Chiapas, Guerrero, Oaxaca, Veracruz \\
\hline & 4. C. nelsoni & & Chiapas \\
\hline \multirow[t]{3}{*}{ 3. Crus-galli } & 5. C. gracilior & & $\begin{array}{l}\text { Hidalgo, Puebla, Tamaulipas, Estado de México, Veracruz, San } \\
\text { Luis Potosí, Oaxaca, Michoacán }\end{array}$ \\
\hline & 6. C. rosei & parryana & $\begin{array}{l}\text { Tamaulipas, San Luis Potosí, Nuevo León, Hidalgo } \\
\text { Chihuahua, Coahuila, Nayarit, Durango, Guanajuato, León, } \\
\text { Hidalgo, Tamaulipas, Nuevo Sinaloa, Queretaro, San Luis Potosí } \\
\text { Tamaulipas, Nuevo León, San Luis Potosí } \\
\text { Coahuila, Nuevo León }\end{array}$ \\
\hline & & $\begin{array}{l}\text { rosei mahindae } \\
\text { rosei amoena }\end{array}$ & \\
\hline \multirow[t]{2}{*}{ 4.Madrenses } & 7.C. tracyi & $\begin{array}{l}\text { tracyi } \\
\text { coahuilensis } \\
\text { madrensis }\end{array}$ & $\begin{array}{l}\text { Texas, EUA } \\
\text { Coahuila } \\
\text { Coahuila, Nuevo León }\end{array}$ \\
\hline & 8. C. aurescens & & Coahuila, Nuevo León \\
\hline \multirow[t]{4}{*}{ 5. Greggianae } & 9. C. greggiana & $\begin{array}{l}\text { greggiana } \\
\text { pepo }\end{array}$ & $\begin{array}{l}\text { Coahuila, Nuevo León, Tamaulipas, Texas, EUA } \\
\text { Coahuila, Nuevo León }\end{array}$ \\
\hline & 10. C. serratissima & & $\begin{array}{l}\text { Hidalgo y probablemente Querétaro, San Luis Potosí, Nuevo } \\
\text { León }\end{array}$ \\
\hline & 11. C. sulfurea & & Coahuila, Nuevo León \\
\hline & 12. C. grandifolia & grandifolia potosina & Coahuila, Nuevo León \\
\hline \multirow[t]{3}{*}{ 6) Baroussanae } & 13. C. baroussana & Baroussana jamensis & $\begin{array}{l}\text { Coahuila, Nuevo León } \\
\text { Coahuila }\end{array}$ \\
\hline & 14. C. cuprina & & Nuevo León \\
\hline & 15. C. johnstonii & & Coahuila \\
\hline
\end{tabular}

Table 1: Taxonomic classification of the genus Crataegus. 


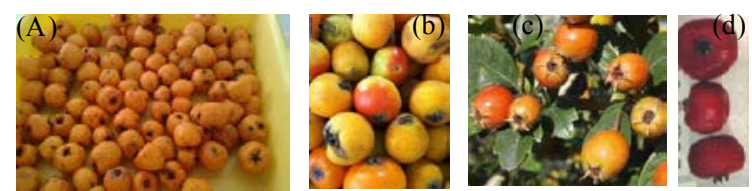

Figure 1: Phenotipic characteristics of three different varieties of hawthorn in Mexico. (A) C. mexicana, (B) C. gracilor, (C) C. nelsoni. (D) C. greggiana.

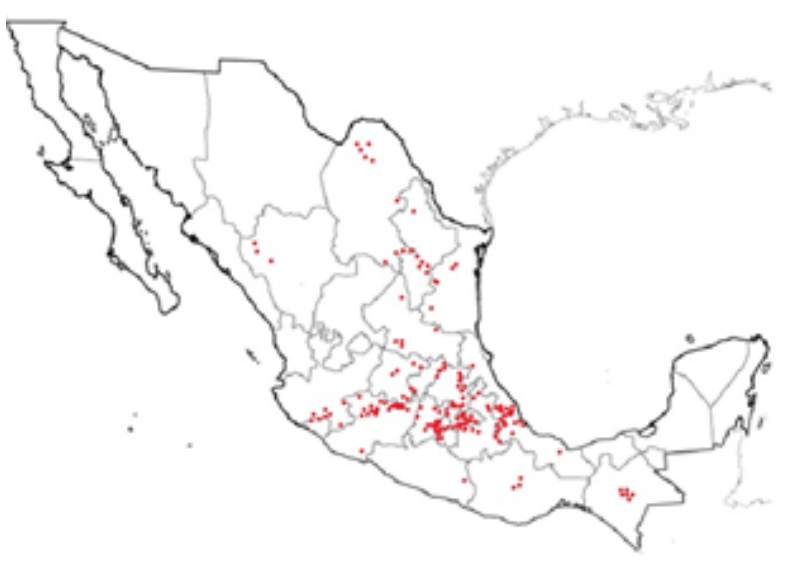

Figure 2: Distribution in México of hawthorn Crataegus.

\section{Etnobotanic Uses and Applications of "Tejocote" in Different Diseases}

There is evidence that the fruit of Crataegus were used and consumed by humans since 7,000 years B.C. in Turkey and Siria [8]. The leaves and flowers in an infusion (tea) are used for kidney diseases, to lose weight as well, since it is an excellent diuretic and cleans urinary tracks, it moderates the contractions in case of tachicardy and is used as anti-spasm; the root and tree bark are also utilized as excellent antispasm [7]. Some types of Crataegus in Europe and China are used as remedy for heart diseases, above all because it has a cardiotonic effect good to stabilize blood pressure [2,24], possibly due to its contents of flavonoids. Fruit and flowers of the type Crataegus have components with anti-oxidant potential [25], among them the epicatechin acid and chlorogenic acid [24,26] (Table 2).

\section{Nutritional Characteristics}

The fruit, leaves and flowers of the type Crataegus are very appreciated by its contents of Vitamin A (1) and C (2) [9], carotenoids and mineral salts such as calcium, phosphorus and iron, besides that it has a high content of pectin $[27,28]$ and sugars [21]. Also has been reported the presence of saponins, tanins, cardiotonic amines (phenylethylamine (3), tyramine (4), isobutylamine (5), o-methoxyphenylmethylamine (6), choline and acetylcholine (7), derived of purine (adenosine, adenine, guanine, caffeic acid (8) amygdalin (9) [29] (Figure 3). According to the nutritional values of food [30], the nutritional contents of tejocote for each 100 grams of fruit, is shown on (Table 3). The contents of Vitamin C in tejocote varies among different authors, in a rank of values from $45.66 \mathrm{mg} / 100$ grams [30], 38.6-49.7 $\mathrm{mg} / 100$ grams [1], 40-75 mg/100 grams [14], nevertheless, the authors do not specify the variety of "tejocote" that are reporting, for that it can be suggested that the difference in its composition is due to the variability of the fruit, its origin and its production.
The contents of malic acid in varieties of C. Mexicana $D C$ in the state of México is of 1-6\% [21] and in C. spp is of $0.99-2.85 \%$ in fruit collected in Puebla and Oaxaca [1].

\section{Phytochemical Composition}

The bibliographical review performed for this investigation, reported few papers referring to the composition and contents of secondary anti-oxidant metabolites of "tejocote" Crataegus mexicana, possibly due to the great variety of species of "tejocote" in México (Table 1). Nevertheless, in the leaves, fruit, roots and tree barks from other medicinal varieties of Crataegus in Asia, Europe and North America, there have been found high concentrations of diverse secondary metabolites, such as bi-flavonoids, oligomeric procyanidines of flavanols, phenolic acids, tri-terpenic acids, organic acids and sterols, epicatechin and catechin [31,11]. Also they contain an important quantity of pectines, rutin and tannines [7,24,26]. Recently, in studies performed to the fruit of "tejocote" in genetic varieties of Asia and Europe, it has been demonstrated the presence of terpenoids, polyphenols, (catechins - mainly epicatechin-, polymeric proantocynidines and oligomeric, such as dimeric procyanidine $B_{2}$, cyanidine-3-O-galactoside, idaein and chlorogenic acid) and flavonoids (flavonol-O-glycoside like quercetin-3-O-galactosido, vitexine-2"-Oramnoside, acetylvitexin-2"-O-ramnoside, flavone- $C$-glycoside, and hiperoside [31-34].

\section{Carotenoids in Crataegus mexicana}

The chemical molecules are going to have highly specialized functions inside a biological system and this specialization is determined right by the availability or electronic scarcity within the main molecular characteristics from the structure and/or electronic point of view. The carotenoids are a family of phytochemicals that present intense coloring: yellow, orange and red, these are synthesized by plants and microorganisms, but not by animals. Biologically are substances that protect plants and fruit from solar radiation, it means they are photo-protectors due to its high electronic conjugation in its chemical structure.

There is a presence of carotenoids in the fruit of "tejocote". For each gram of weight there are $26.44 \mathrm{mg}$. of carotenes in the "tejocote" epidermis Crataegus mexicana [25]. From the extracts of "tejocote" there have been identified with the IR techniques, RMN, ${ }^{1} \mathrm{H},{ }^{13} \mathrm{C}$ and mass spectrometry, the presence of the carotenoid $\beta$-carotene (10) [35]. It is very likely that the yellow color in the epidermis of the "tejocote" is given by the carotenoids.

\section{Flavonoids in Crataegus mexicana}

It is known that flavonoids are bio-synthesized by means of the Shikimic acid route in plants, concerning the Crataegus mexicana; there have been detected some flavonoids such as quercetin and its derivations glycones type. The flavonoids are not essential for the survival of the "tejocote", nevertheless, they play a determinant role in providing color, protection from high solar energy rays and also provide protection against pathogen agents [36]. On the epidermis of the fruit, there is a large variety and high concentration of metabolites that have the functions of protecting against pathogen agents, insect attacks, scaring processes. This high concentration of metabolites on the epidermis has as a result a diversity of biological activity, mainly 
Citation: Antonio BTJ, Margarita CR, Daniel MI (2015) Biological Properties and Antioxidant Activity of Hawthorn Crataegus mexicana. J Pharmacogenomics Pharmacoproteomics 6: 153. doi:10.4172/2153-0645.1000153

Page 4 of 8

\begin{tabular}{|c|c|c|c|c|}
\hline Especie & Part/Extract & Use/ Biological activity & Country & Reference \\
\hline mexicana & $\begin{array}{l}\text { Extract } \\
\text { Root infusion } \\
\text { Hexane extracts from leaf } \\
\text { Peel extract }\end{array}$ & $\begin{array}{l}\text { Diabetes } \\
\text { Hypoglucemic } \\
\text { Myorelaxing } \\
\text { Antioxidant } \\
\text { Antioxidant, inhibit erypthosis }\end{array}$ & Mexico & $\begin{array}{l}{[49]} \\
{[50]} \\
{[42]} \\
\\
\\
{[25]}\end{array}$ \\
\hline pubesens & Fruit & Cardiovascular diseases & Mexico & {$[51,52]$} \\
\hline $\begin{array}{l}\text { Sp } \\
\text { stipulosa, mexicana, } \\
\text { nelsoni }\end{array}$ & $\begin{array}{l}\text { Boiled fruit } \\
\text { Leaf and flower infusion } \\
\text { Root and bark } \\
\text { Flowers }\end{array}$ & $\begin{array}{l}\text { Respiratory tract diseases, cough, bronchitis, } \\
\text { pneumonia, cool, chest congestion, chest pain } \\
\text { Kidney diseases, slender, diuretic, urinary tract } \\
\text { cleaner, tachycardia moderator, antispasmodic } \\
\text { Antispasmodic } \\
\text { Antioxidant }\end{array}$ & Mexico & {$[40]$} \\
\hline curysipala & Hydro-alcoholic extract & $\begin{array}{l}\text { Diminish diastolic and systolic pressure in arterial } \\
\text { hypertension }\end{array}$ & & [53] \\
\hline Crataegus sp & Methanol extract of fresh fruits & $\begin{array}{l}\text { Inhibitor of the of angyotensin enzyme converter } \\
\text { AEC }\end{array}$ & & {$[54]$} \\
\hline aronia & Leaf and fruit & $\begin{array}{l}\text { Cardiovascular diseases, cancer, diabetes, sexual } \\
\text { disorders, antioxidant }\end{array}$ & Arabia, France & $\begin{array}{l}{[55,56]} \\
{[52]}\end{array}$ \\
\hline pinntiflda & Nd fruit & Cardiovascular diseases & China & {$[51,52]$} \\
\hline pinnatifida & $\mathrm{Nd}$, dryed fruits & Diminish plasm lipids & China, Taiwan & {$[57,58]$} \\
\hline cuneata & $\mathrm{Nd}$ fruit & Cardiovascular diseases & Japan & {$[51,52]$} \\
\hline monogyna & Nd fruit & Cardiovascular diseases & Europe & {$[51,52]$} \\
\hline $\begin{array}{l}\text { oxycantha } \\
\text { oxyacantha }\end{array}$ & $\begin{array}{l}\text { Nd fruit } \\
\text { Extract } \\
\text { Alcoholic extract }\end{array}$ & $\begin{array}{l}\text { Cardiovascular diseases } \\
\text { Cardiotonic, antiarrhythmic } \\
\text { Inhibitor of lipoperoxidation } \\
\text { Prevent the ischemic infarct } \\
\text { Diminish congestive cardiac fail }\end{array}$ & Med west & $\begin{array}{l}{[51,52,59]} \\
{[60]} \\
{[61]} \\
{[62]}\end{array}$ \\
\hline aronica & Aqueous extract of fruit & $\begin{array}{l}\text { Cardiovascular diseases } \\
\text { Diminish lipids }\end{array}$ & USA, Israel & {$[51,52]$} \\
\hline phaenopyrum & Aqueous extract of fruit & Cardiovascular diseases & USA, Israel & {$[51,52]$} \\
\hline ambigua & Aqueous extract of fruit & Cardiovascular diseases & Rusia & {$[51,52]$} \\
\hline tanacetifolia & $\begin{array}{l}\text { Hydroperoxide and aqueous extract of leafs } \\
\text { Fruit extract }\end{array}$ & $\begin{array}{l}\text { Prevent hypertension in rats and cardiovascular } \\
\text { diseases } \\
\text { Hypotensor }\end{array}$ & & $\begin{array}{l}{[63]} \\
{[64]}\end{array}$ \\
\hline meyeri & Hydro-alcoholic extract of flowers & Cardiotonic, antiarrhythmic, hypotensor & & [61] \\
\hline laevigata & Leaf extract & Antioxidant & & {$[65]$} \\
\hline pentaegyna & Fruit extract & Antioxidant & Iran & {$[66]$} \\
\hline Folium & Fruit extract & & Turkey & [67] \\
\hline
\end{tabular}

Table 2: Ethnobotanical and applications of the genus Crataegus.

\begin{tabular}{|c|c|c|c|c|}
\hline Species & Part & Flavonoid content & Structure & Reference \\
\hline spp & $\begin{array}{l}\text { Ethanolic extract from } \\
\text { flowers }\end{array}$ & Quercetin-3-O-glucoside & 11 & [40] \\
\hline $\begin{array}{l}\text { stipulosa } \\
\text { nelsoni }\end{array}$ & $\begin{array}{l}\text { Ethanolic extract from } \\
\text { flowers }\end{array}$ & Quercetin-3-O-ramnóside & 12 & [40] \\
\hline mexicana & $\begin{array}{l}\text { Ethanolic extract from } \\
\text { flowers }\end{array}$ & Quercetin-3-O-ramnosil-(1->6)-glucoside (rutin) & 13 & [40] \\
\hline spp & $\begin{array}{l}\text { Ethanolic extract from } \\
\text { flowers }\end{array}$ & Quercetin-3-O-ramnosil.(1->2)-[ramnosil-(1->6]-glucoside & 14 & {$[40]$} \\
\hline
\end{tabular}

Table 3: Nutrimental content in Mexican hawthorn (for each $100 \mathrm{~g}$ ). 
Citation: Antonio BTJ, Margarita CR, Daniel MI (2015) Biological Properties and Antioxidant Activity of Hawthorn Crataegus mexicana. J Pharmacogenomics Pharmacoproteomics 6: 153. doi:10.4172/2153-0645.1000153

anti-microbial, anti-fungicide and anti-oxidant [37]. The concentration of flavonoids depends on environmental factors, such as hydric stress, solar intensity and the type of ground, mainly [38]. The database of the USDA (United States of America), about the contents of flavonoids in food, reports the contents of metabolites in the leaves of the "tejocote" and its root (without specifying the family), indicating the presence of flavonoids, like apigenine (prom: 0.40). Also the presence of flavonols, like quercetin (prom: 24.10) (USDA database for flavonoid content in selected aliments, 2011, values taken from [39]).

In ethanolic extracts from the flowers of Mexican varieties, they have been determined by means of HPLC, the presence of the flavonoids: quercetin 3-O-glucoside, quercetin 3-O-ramnoside, quercetin 3-O-ramnosil-(1-6)-glucoside, and quercetin 3-O-ramnosil1-2-[ramnosil 1-6]-glucoside [6,40] (Figure 4) (Table 4).

The total content and its phenolic compounds in the "tejocote" (Crataegus mexicana) with anti-oxidant activity, is very different according to the different authors $[21,35]$.

The contents of polyphenols in the epidermis of the Crataegus mexicana is of $2.65 \mathrm{mg}$ (content equivalent in $\mathrm{mg}$ of gallic acid/g) $[35,25]$. Also in other varieties in other parts of the world differs in its concentration. (Table 5). This can be due to the type and the moment of the harvest, to the part of the plant being studied and the level of ripeness, as well as the kind of analysis used. Considering these differences, the flavonoids are extracted in a better way using polar solvents [41]. In Crataegus mexicana the only studies about flavonoids and their effects have been performed with acetone extracts and their effects to inhibit the lipo-peroxidation in rat brain cells [25] and in erythrocytes, ethanolic extracts in order to determine the antioxidant action $[6,14,40]$, and $n$-hexane extracts, dichloromethane and methanol in order to determine its relaxing action in the trachea of Ghinnea pigs [42].

\section{Anti-Oxidant Activity of the "Tejocote"}

On different research works have been demonstrated the antioxidant activity of different varieties of howthorn in the world. Nevertheless, the Mexican varieties of "tejocote" have been studied much less concerning its anti-oxidant activity $[6,14,25,40]$. Méndez et al., [25] reports the anti-oxidant action in rat brain cells, with extracts of acetone and methanol from the skin of "tejocote", due to, possibly its contents of flavonoids; in the anti-oxidant evaluation it was measured the level of inhibition of lipo-peroxidation in vitro in the brain tissue of a male Wistar rat, where the peroxidation of lipids is induced in the brain of the rat with $\mathrm{FeSO}_{4}$ and at the end of this process it was quantified the Malondihaldehyde (MDA) with Thiobarbituric acid (TBA) for the generation of chromophor (MDA-TBA), by means of spectrophotometric measuring to $540 \mathrm{~nm}$. The formation of MDA was inhibited by the action of anti-oxidants in the skin of the "tejocote" (Crataegus mexicana) in a percentage of $83 \%$, to a concentration of $100 \mathrm{mg} / \mathrm{L}$ of the acetone extract. The chemical reaction is shown on (Figure 5). Similarly Banderas et al., 2015, but using human red blood cells, showed the inhibitory antioxidant effect of acetone extracts on the morphology of the cell membrane and in the erypthosis process during long periods of time. Nevertheless, the metabolites present in the acetone extract have not been completely elucidated.

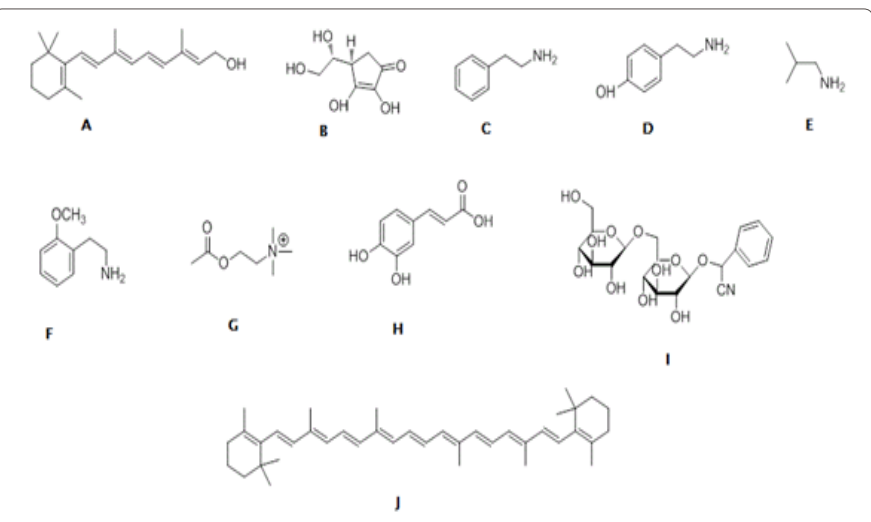

Figure 3: A. vitamin A, B. vitamin C, C. phenylethylamine, D. tyramine, E. isobutylamine, F. o-methoxy-phenylmethylamine, G. acetylcholine, H. caffeic acid, I. amygdalin, J. carotenoid ( $\beta$-carotene).<smiles>O=c1c(O)c(-c2ccc(O)c(O)c2)oc2cc(O)ccc12</smiles>

\begin{tabular}{|l|l|}
\hline Metabolite & Substitution (R) \\
\hline Querctin & R=H \\
\hline 11 & R= Rham-Fham-Glv- \\
\hline 12 & R=Rham-Gh- \\
\hline 13 & R=Glv- \\
\hline 14 & R=Rham- \\
\hline
\end{tabular}

Figure 4: Structure of quercetin glucosides.

\section{Conclusion and Future Research}

The revision of the literature about the bio-chemical composition of the hawthorn showed that it is known the chemical composition of 27 different species of Crataegus, from which there are different hybrid species in different parts of the world. Many of them have not been studied completely, concerning their contents of metabolites neither for their nutraceutic properties on human beings, such is the case of Crataegus mexicana or Mexican "tejocote". This is surprising, 
Citation: Antonio BTJ, Margarita CR, Daniel MI (2015) Biological Properties and Antioxidant Activity of Hawthorn Crataegus mexicana. J Pharmacogenomics Pharmacoproteomics 6: 153. doi:10.4172/2153-0645.1000153

Page 6 of 8

\begin{tabular}{|c|c|c|c|c|c|}
\hline Specie & Part & Phenols & Flavonoids & Carotenoids & Reference \\
\hline mexicana & Fruit skin & $\begin{array}{l}2.65 \pm 0.23 \mathrm{mg} \\
\text { gallic acid / gramo }\end{array}$ & SD & $26.4 \pm 0.02 \mathrm{mg} / \mathrm{g} \beta$-carotene & {$[25]$} \\
\hline mexicana DC & Pulp of the fruit & $\begin{array}{l}8.1-22.3 \mathrm{mg} / \mathrm{g} \text { tannic acid } \\
\text { equivalent }\end{array}$ & SD & SD & [21] \\
\hline mexicana & $\begin{array}{l}\text { Ethanolic extract of the } \\
\text { flower }\end{array}$ & $\begin{array}{l}11.02 \pm 0.48 \\
7.77 \pm 1.25 \\
\text { mg phenol equivalent }\end{array}$ & $\begin{array}{l}2.85 \pm 0.09 \\
7.23 \pm 0.08 \\
\text { Quercetin } / 1 \mathrm{~g} \text { dry weight }\end{array}$ & SD & {$[40]$} \\
\hline
\end{tabular}

Table 4: Biochemical characterization of flavonoids in Crataegus mexicana.

\begin{tabular}{|c|c|c|c|c|c|}
\hline Specie & Part & Phenols & Flavonoids & Carotenoids & Reference \\
\hline mexicana & Fruit skin & $\begin{array}{l}2.65 \pm 0.23 \mathrm{mg} \\
\text { gallic acid / gramo }\end{array}$ & SD & $\begin{array}{l}26.4 \pm 0.02 \mathrm{mg} / \mathrm{g} \\
\beta \text {-carotene }\end{array}$ & [25] \\
\hline mexicana DC & Pulp of the fruit & $\begin{array}{l}\text { 8.1-22.3 } \mathrm{mg} / \mathrm{g} \text { tannic acid } \\
\text { equivalent }\end{array}$ & SD & SD & [21] \\
\hline mexicana & $\begin{array}{l}\text { Ethanolic extract of the } \\
\text { flower }\end{array}$ & $\begin{array}{l}11.02 \pm 0.48 \\
7.77 \pm 1.25 \\
\text { mg phenol equivalent }\end{array}$ & $\begin{array}{l}2.85 \pm 0.09 \\
7.23 \pm 0.08 \\
\text { Quercetin /1g dry weight }\end{array}$ & SD & [40] \\
\hline
\end{tabular}

Table 5: Flavonoids and carotenoids content in the genus Crataegus.

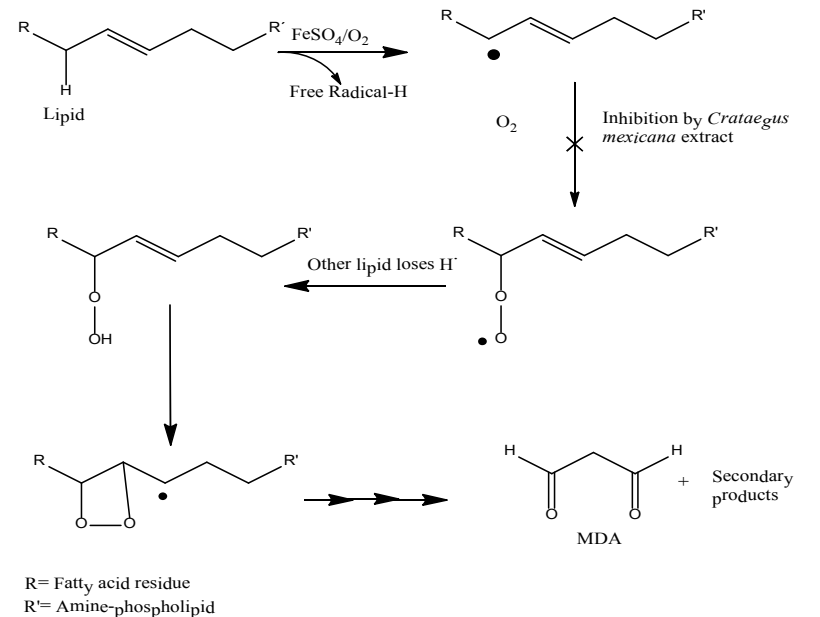

Figure 5: Malondihaldehyde (MDA) reaction with Thiobarbituric acid (TBA) to generate the cromopher (MDA-TBA).

since its wide use in Traditional Medicine and its high consumption in the country. The medicinal properties of this fruit, considering its pharmacological activities as a traditional use fruit, is demonstrated in vitro for its anti-oxidant action, in animals and in humans as well, its potential as an anti-glucemic, cardiotonic and miorelaxing fruit. The presence of carotenes, polyphenols and flavonoids could be related to these biological functions, not individually, but probably acting sinergically.

Up to 2012 [31], there are only two studies that have identified some flavonoids in extracts from "tejocote", and analyzed its biological function [43,44], determining the cardiotonic effect and in the regulation of blood pressure. The majority of studies only report the effects of the extracts by themselves, and not of individual components. The current status of the research about the type Crataegus mexicana, still leaves an extensive field of research in order to know is bio-chemical composition and the biological activity of its components. Very few species have been studied, mainly in Europe and Asia. Nevertheless, in México the information is little about the bio-chemical composition and the biological components contained in the "tejocote", its biological activity and its mechanisms of action in the organism, since it is used to treat many diseases. It is necessary to homogeneizate the used methods for the selection of the type of "tejocote" in México, the selection of the part of the plant to be studied, the extraction of the extract, to purify its components, determine the contents of components, in order to perform the necessary clinical studies and determine its biological properties, since it is important having factual data and the comparatives with each type of analysis. There are many components in the different studied species in the world, the same would happen with the varieties found in México, as well they could have other type of components that have not been purified and studied yet in its biological activity, that is why it is important the unification of criteria in the study, since that takes a great deal of research work and puts efforts together to perform the necessary studies about the Mexican "tejocote".

It is necessary to perform more research about the bio-chemical contents of metabolites in Crataegus mexicana, with the purpose of performing clinical epidemiological studies, which may allow to recognize the biological effect to treat diseases in a pharmacological way and not in an empirical way, which will allow to regulate commercial and pharmacologically the generated products and authorized by the Health Authorities. The problem is the genetic varieties and the wide use if their parts, which creates confusion in order to analyze and compare results. Nevertheless, the Crataegus metabolites profile can be studied by means of isolating them by preparative high performance liquid chromatography (HPLC) and then know its chemical structure by the infrared techniques (IR), nuclear magnetic resonance hydrogen and carbon $13\left(\mathrm{MNR}{ }^{1} \mathrm{H},{ }^{13} \mathrm{C}\right)$, mass spectrometry (MS) and, if possible with solids or crystals molecules by X-Ray diffraction will be used.

More than 25\% of pharmacological prescriptions are medication obtained or synthesized from medicinal plants, and only $1 \%$ of them have been scientifically evaluated [45-49], only a few have the endorsement of Health Authorities in some countries of the world such as Europe [46], China [47] and in North America they are sold as food and food supplement [48-55]. In México, the products derived from "tejocote" are sold mainly as preserved fruit, jelly, candy, extract, wine and in capsules, derived from the leaves, flowers and fruit of the variety Crataegus mexicana [56-65]. Depending on the type of fruit, there is a 
wide variety on the contents of molecules that differ in each case, the part that is analyzed, the form of preparation of the fruit and the form of extraction, including the polyphenols. From here is the necessity of knowing in depth its contents of biologically active substances [66-72]. Determine if they act in an isolated way or the activity is increased when the present metabolites in the extract of "tejocote" are combined among them. It is necessary to design research on controlled clinical essays (cases and controls) [73-75] to evaluate its function, of the fruit, in humans, sick as well as healthy. Therefore propose new presentations of food products made upon a hawthorn base, that preserves its biological and antioxidant properties. Right there is where the biotechnological techniques should be applied, in order to preserve it to increase the availability of this hawthorn out of season.

\section{Acknowledgment}

This study was partially supported by grant 105663-CB-2008 from the Mexican Council of Science and Technology (CONACYT) and by grant from the Universidad Autónoma de Tlaxcala CACyPI-2014. We also acknowledge to CONACYT for providing the financial support (54150) to José Antonio Banderas Tarabay during his Ph.D. studies in the Universidad Autónoma de Tlaxcala. Also we thank to Ms Maria S Linares Cinco for helping in the translation of the manuscript.

\section{References}

1. Nieto-Ángel R (2007) Colección, conservación y caracterización del tejocote (Crataegus spp). En: AR Nieto (Ed). Frutales nativos, un recurso filogenético en México, UACH, México.

2. Nieto-Ángel R, Borys MW (2008) Germoplasma y usos del tejocote en México. Enfoques tecnológicos en la fruticultura, $\mathrm{UACH}$, México.

3. Cabrera LG (1992) Diccionario de Aztequismos. Ediciones Colofón, Distrito Federal, México.

4. Nieto-Ángel R, Borys MW (1993) El tejocote (Crataegus spp); un potencial frutícula de zonas templadas. Revista Fruticultura Profesional 54: 64-71.

5. Martínez M (1994) Catálogo de nombres vulgares y científicos de plantas mexicanas. Fondo de Cultura Económica.

6. García-Mateos R, Ibarra-Estrada E, Nieto-Angel R (2013) Antioxidant compounds in hawthorn fruits (Crataegus spp.) of Mexico. Revista Mexicana de Biodiversidad 84:1298-1304

7. Argeta VA, Cano AL (1994) Atlas de las plantas de la medicina tradicional mexicana. Instituto nacional Indigenista, México.

8. López-Santiago J, Nieto-Ángel $R$, Barrientos-Priego AF, Rodríguez-Pérez E, Colinas-León MT, et.al. (2008) Selección de variables morfológicas para la caracterización del tejocote (Crataegus spp.) Revista Chapingo. Serie horticultura 14: 97-111.

9. Nuñez-Colín CA, Sánchez Vidaña DI (2010) Ethnobotanical, cultural, and agricultural uses of tejocote (Crataegus species) in Mexico. XXVIII International Horticultural Congress on Sciences and Horticulture for people: III International Symposium on Plant Genetic Resources. Acta Horticulturae 918.

10. Phipps JB (1983) Biogeographic, taxonomic, and cladistic relationships between East Asiatic and North American Crataegus. Annals of the Missouri Botanical Garden 70: 667-700.

11. Kumar D, Arya V, Bhat ZA, Khan NA, Prasad DN (2012) The genus Crataegus: chemical and pharmacological perspectives. Rev Bras Farmacogn Braz J Pharmacogn 22: 1187-1200.

12. Phipps JB, O’Kennon RJ, Lance RW (2003) Hawthorns and medlars. Timber Press, Portland, USA.

13. Nuñez-Colín CA (2008) Variabilidad inter e intra específica del germoplasma de tejocote (Crataegus spp.) del centro y sur de México. Tesis Doctoral Instituto de Horticultura Universidad Autónoma Chapingo, México.

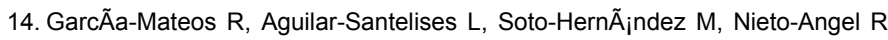
(2013) Flavonoids and antioxidant activity of flowers of Mexican Crataegus spp. Nat Prod Res 27: 834-836.

15. Nuñez-Colín CA, Hernández-Martínez MA (2011) La problemática en la taxonomía de los recursos genéticos de tejocote (Crataegus spp.) en México. Rev Mex Cienc Agric 2: 141-153.
16. Eggleston WW (1909) The Crataegi of Mexico and Central America. Bulletin of the Torrey Botanical Club 36: 501-514.

17. Phipps JB, Robertson KR, Smith PG, Roher JR (1990) A checklist of the subfamily Maloideae (Rosaceae). Can J Bot 68: 2209-2269.

18. Phipps JB (1997) Monograph of northern Mexican Crataegus (Rosaceae subfam. Maloideae). SIDA Botanical Miscellany 15: 1-94.

19. McVaugh R (2000) Botanical results of the Sessé \& Mociño expedition (17871803). VII. A guide to relevant scientific names of plants. Hunt Institute for botanical documentation and Carnegie Mellon University, Pittsburgh.

20. Nuñez-Colín CA, Nieto-Ángel R, Barrientos-Priego AF, Segura S, SahúnCastellanos J, et.al. (2008) Distribución y caracterización eco-climática de género Crataegus L. (Rosaceae, Subfam. Maloideae) en México. Revista Chapingo Serie horticultura 14: 177-184.

21. Franco-Mora O, Aguirre-Ortega S, Morales-Rosales EJ, González-Huerta A, Gutiérrez-Rodríguez F (2010) Caracterización morfológica y bioquímica de frutos de tejocote (Crataegus mexicana DC.) de Lerma y Ocoyoacac, México. 17: 61-66.

22. El-Sayed AM (2011) The pherobase: Database of Insect Pheromones and Semiochemicals.

23. Phipps JB (1998) Introduction to the red fruited hawthorns (Crataegus, Rosaceae) of western North America. Can J Bot 76: 1863-1899.

24. Özcan M, Hacseferogullari H, Marakoglu T, Arslan D (2005) Hawthorn (Crataegus spp) Fruit: Some physical and chemical properties. J Food Eng 69: 409-413.

25. Méndez-Iturbide D, Banderas-Tarabay JA, Nieto-Camacho A, Rojas-Chávez A, García-Meza G (2013) Antioxidant capacity of extracts from hawthorn (Crataegus mexicana) skin. African Journal of Food Science 7: 150-158.

26. Peschel W, Bohr C, Plescher A (2008) Variability of total flavonoids in Crataegus-factor evaluation for the monitored production of industrial starting material. Fitoterapia 79: 6-20.

27. Higareda RA, Salazar-Montoya JA, Ramos-Ramírez EG (1995) Conservación poscosecha del tejocote (Crataegus mexicana). Revista Chapingo. Serie Horticultura 4.

28. Nuñez-Colín CA (2009) The tejocote (Crataegus species): a Mexican plant genetic resources that is wasted. A review. Acta Hortic 806: 339-346.

29. Verma SK, Jain V, Verma D, Khamesra R (2007) Crataegus oxyacantha- a cardioprotective herb. J Herbal Med Toxicol 1: 65-71.

30. Pérez-Lizaur AB, Palacios-González B (2009) Sistema de alimentos equivalentes para pacientes renales. Fomento de nutrición y salud, A.C México.

31. Edwards JE, Brown PN, Talent N, Dickinson TA, Shipley PR (2012) A review of the chemistry of the genus Crataegus. Phytochemistry 79: 5-26.

32. Froehlichera T, Hennebelle T, Martin-Nizard F, Cleenewerck P, Hilbert JL, et.al (2009) Phenolic profiles and antioxidative effects of hawthorn cell suspensions, fresh fruits, and medicinal dried parts. Food Chem 115: 897-903.

33. Song SJ, Li LZ, Gao PY, Peng Y, Yang JY, et al. (2011) Terpenoids and hexenes from the leaves of Crataegus pinnatifida. Food Chem 129: 933-939.

34. Caliskan O, Gündüz K, Serçe S, Toplu C, Kamiloglu O, et.al. (2012) Phytochemical characterization of several hawthorn (crataegus spp.) species sampled from the Eastern Mediterranean region of Turkey. Pharmacogn Mag 8: 16-21.

35. Rojas-Chávez A (2011) Evaluación de la actividad antioxidante de la epidermis del fruto de tejocote (Crataegus mexicana). Tesis de Maestría en Ciencias Biológicas, Universidad Autónoma de Tlaxcala, Tlaxcala.

36. Buer CS, Imin N, Djordjevic MA (2010) Flavonoids: new roles for old molecules $\mathrm{J}$ Integr Plant Biol 52: 98-111.

37. Havsteen BH (2002) The biochemistry and medical significance of the flavonoids. Pharmacol Ther 96: 67-202.

38. Liu R-H, Yu B-Y, Qiu S-X, Zheng D (2005) Comparative analysis of eight majo polyphenolic components in leaves of Crataegus L. by HPLC. Chin J Nat Med 3: 162-167. 
Citation: Antonio BTJ, Margarita CR, Daniel MI (2015) Biological Properties and Antioxidant Activity of Hawthorn Crataegus mexicana. J Pharmacogenomics Pharmacoproteomics 6: 153. doi:10.4172/2153-0645.1000153

Page 8 of 8

39. Skegret M, Kotnik P, Hadolin M, Hraš AR, Simonic M, Knez Z (2005) Phenols, proanthocyanidins, flavones, and flavonols in some plant materials and their antioxidant activities. Food Chemistry 89: 191-198.

40. García-Mateos R, Aguilar-Santelises L, Soto-Hernández M, Nieto-Angel $R$, Kite $G$ (2012) Total phenolic compounds, flavonoids and antioxidant activity in the flowers Crataegus spp. From Mexico. Agrociencia 46: 651-662.

41. Liu P, Kallio H, LÃ D, Zhou C, Ou S, et al. (2010) Acids, sugars, and sugar alcohols in Chinese hawthorn (Crataegus spp.) fruits. J Agric Food Chem 58: 1012-1019.

42. Arrieta J, Siles-Barrios JD, García-Sánchez J, Reyes-Trejo B, SánchezMendoza ME (2010) Relaxant effect of the extracts of Crataeugus mexicana on guinea pig tracheal smooth muscle. Pharmacognosy Journal 2: 40-46.

43. 43. Schüssler M, Hölzl J, Fricke U (1995) Myocardial effects of flavonoids from Crataegus species. Arzneimittelforschung 45: 842-845.

44. Ammon HP, Handel M (1981) Crataegus, toxicology and pharmacology. Part II: Pharmacodynamics (author's transl). Planta Med 43: 209-239.

45. Lambert J, Srivastava J, Vietmeyer N (1997) Medicinal plants, Rescuing a global heritage. The World Bank, Washington. DC.

46. Blumenthal M (1998) The complete German commission E monographs: therapeutic guide to herbal medicines. American Botanical Council, Austin TX.

47. Liu Y, Wang MW (2008) Botanical drugs: challenges and opportunities: contribution to Linnaeus Memorial Symposium 2007. Life Sci 82: 445-449.

48. Rates SM (2001) Plants as source of drugs. Toxicon 39: 603-613.

49. Rigelsky JM, Sweet BV (2002) Hawthorn: pharmacology and therapeutic uses. Am J Health Syst Pharm 59: 417-422.

50. Andrade-Cetto A, Heinrich M (2005) Mexican plants with hypoglycaemic effect used in the treatment of diabetes. J Ethnopharmacol 99: 325-348.

51. Khalil R, Abuharfeil N, Shabsoug B (2008) The effect of Crataegus aronica aqueous extract in rabbits feed with high cholesterol diet. Eur J Sci Res 22: $352-360$.

52. Ljubuncic P, Portnaya I, Cogan U, Azaizeh H, Bomzon A (2005) Antioxidant activity of Crataegus aronia aqueous extract used in traditional Arab medicine in Israel. J Ethnopharmacol 101: 153-161.

53. Asgary S, Naderi GH, Sadehi M, Kelishadi R, Amiri M (2004) Antihypertensive effect of Iranian Crataegus curvisepala Lind: a randomized, double-blind study. Drugs Under Experimental and Clinical Research 30: 221-225.

54. Inokuchi J, Okabe H, Yamauchi T, Nagamatsu A (1984) Inhibitors of angiotensin converting enzyme in crude drugs. I. Chem Pharm Bull (Tokyo) 32: 3615-3619.

55. Miller AL (1998) Botanical influences on cardiovascular disease. Altern Med Rev 3: 422-431.

56. Ju LY (2005) Crataegus oxyacantha (aubepine) in the use as herb medicine in France. Zhongguo Zhong Yao Za Zhi 30: 634-640.

57. Lin Y, Vermeer MA, Trautwein EA (2011) Triterpenic Acids Present in Hawthorn Lower Plasma Cholesterol by Inhibiting Intestinal ACAT Activity in Hamsters. Evid Based Complement Alternat Med 2011: 801272

58. Kao ES, Wang CJ, Lin WL, Chu CY, Tseng TH (2007) Effects of polyphenols derived from fruit of Crataegus pinnatifida on cell transformation, dermal edema and skin tumor formation by phorbol ester application. Food Chem Toxicol 45: 1795-1804.

59. Long SR, Carey RA, Crofoot KM, Proteau PJ, Filtz TM (2006) Effect of hawthorn (Crataegus oxycantha) crude extract and chromatographic fractions on multiple activities in a cultured cardiomyocyte assay. Phytomedicine 13: 643-650.

60. Jayalakshmi R, Thirupurasundari CJ, Niranjali DS (2006) Pretreatment with alcoholic extract of Crataegus oxicantha (AEC) activates mitochondrial protection during isoproterenol -induced myocardial infarction in rats. Mol Cell Biochem 292: 59-67.

61. Garjani A, Nazemiyeh H, Maleki N, Valizadeh H (2000) Effects of extracts from flowering tops of Crataegus meyeri A. Pojark. on ischaemic arrhythmias in anaesthetized rats. Phytother Res 14: 428-431.

62. Degenring FH, Suter A, Weber M, Saller R (2003) A randomized double blind placebo controlled clinical trial of a standardized extract of fresh Crataegus berries (Crataegisan*) in the treatment of patients with congestive heart failure NYHA II. Phytomedicine 10: 363-369.

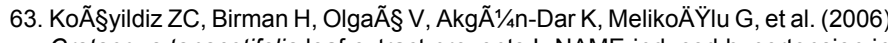
Crataegus tanacetifolia leaf extract prevents L-NAME-induced hypertension in rats: a morphological study. Phytother Res 20: 66-70.

64. Belz GG, Butzer R, Gaus W, Loew D (2002) Camphor-Crataegus berry extract combination dose-dependently reduces tilt induced fall in blood pressure in orthostatic hypotension. Phytomedicine 9: 581-588.

65. Kirakosyan A, Seymour E, Kaufman PB, Warber S, Bolling S, et al. (2003) Antioxidant capacity of polyphenolic extracts from leaves of Crataegus laevigata and Crataegus monogyna (Hawthorn) subjected to drought and cold stress. J Agric Food Chem 51: 3973-3976.

66. Ebrahimzadeh MA, Bahramian F (2009) Antioxidant activity of Crataegus pentaegyna subsp. elburensis fruits extracts used in traditional medicine in Iran. Pak J Biol Sci 12: 413-419.

67. Demiray S, Pintado ME, Castro PML (2009) Evaluation of phenolic profiles and antioxidant activities of Turkish medicinal plants: Tilia argentea, Crataegi folium leaves and Polygonum bistorta roots. Worl Acad sci Eng Technol 54: 312-317.

68. KoÃßyildiz ZC, Birman H, OlgaÃß V, AkgÃ¹/4n-Dar K, MelikoÄŸlu G, et al. (2006) Crataegus tanacetifolia leaf extract prevents L-NAME-induced hypertension in rats: a morphological study. Phytother Res 20: 66-70.

69. De la Cruz-Martínez EM, Nieto-Ángel R, Soriano-García M, Hernández Unzón H (2012) Estudio de los flavonoides de 8 genotipos de tejocote (Crataegus pubescens) y sus uso potencial como alimento funcional. $\mathrm{V}$ Congreso Internacional de Ingeniería Bioquímica, XVI Congreso Nacional de Ingeniería Bioquímica, VI Jornadas Científicas de Biomedicina y Biotecnología Molecular Clave 569449.

70. Kirakosyan A, Kaufman P, Warber S, Zick S, Aaronson K, et al. (2004) Applied environmental stresses to enhance the levels of polyphenolics in leaves of hawthorn plants. Physiol Plant 121: 182-186.

71. Luna-Suárez S, Tapia-López L, López-Valdez F (2010) Efecto del tipo de secado de tejocote sobre el contenido de polifenoles y su comparación con corteza de dos frutos. XII Congreso Nacional de Ciencia y Tecnología de Alimentos, Univ de Guanajuato, Resumen: FH11-FH14.

72. Meneses-Corona A (2011) Evaluación de la actividad antioxidante del fruto de tejocote (Crataegus mexicana) obtenida de dos formas de cultivo. Tesis de Maestría en Ciencias Biológicas, Universidad Autónoma de Tlaxcala, Tlaxcala.

73. Middleton IJ, Kandaswami C, Theoharides TC (2000) The effects of plan flavonoids on mammalian cells: Implications for inflammation, heart disease and cancer. Pharmacological Reviews 52: 673-751.

74. Min BS, Huong HT, Kim JH, Jun HJ, Na MK, et al. (2004) Furo-1,2 naphthoquinones from Crataegus pinnatifida with ICAM-1 expression inhibition activity. Planta Med 70: 1166-1169.

75. WHO (2003) Monographs on medicinal plants newly independent states. 